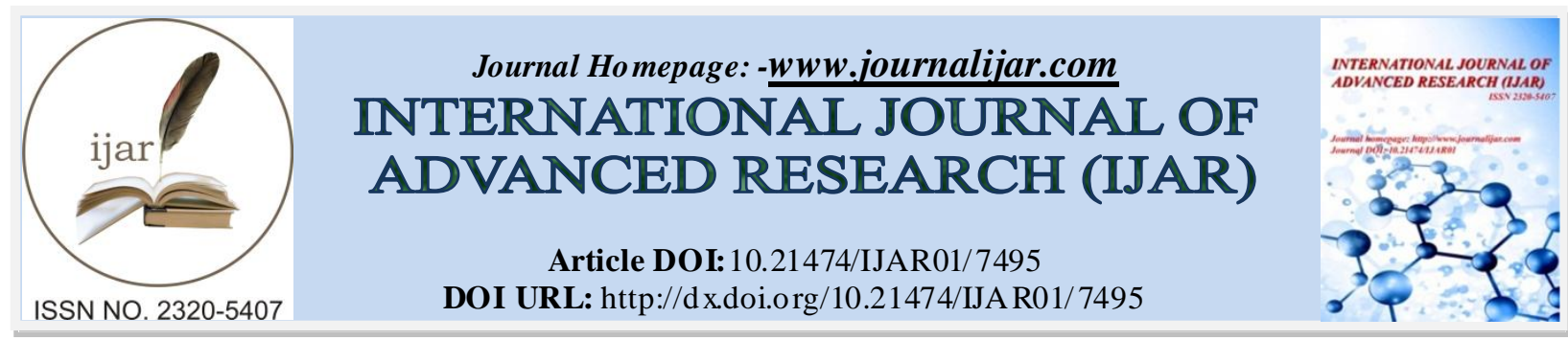

RESEARCH ARTICLE

\title{
EFFECT OF S UPPLEMENTATION WITH GLUTAMINE AND HYDROXYMETHYLB UTIRATE OVER THE CELLS INVOLVED IN WOUND HEALING.
}

\author{
M en C Alejandra Patricia Sal as González ${ }^{1}$, Se villa González María de la Luz $^{2}$ and Fuchs Tarlovsky \\ Vanessa ${ }^{3}$. \\ 1. Hospital General de México/ Instituto Politécnico Nacional. \\ 2. Instituto Politécnico Nacional, Escuela Superior de Medicina. \\ 3. Hospital General de México.
}

\section{Manuscript Info}

(.........................

Manuscript History

Received: 03 June 2018

Final Accepted: 05 July 2018

Published: August 2018

Keywords:-

Wound Healing, glutamine,

Hydroxymethylbut yrate.

\section{Abstract}

Introduction: The healing process demands energy-protein needs higher than the normal requirement. Nutritional support in bloody areas is essential since it restores the capacity of the immune response facilitating healing, promotes angiogenesis and cell proliferation. Objective: To evaluate the effect of glutamine and hydroxymethylbutyrate supplementation on the cells involved in the healing of bloody areas. Methodology: Clinical, experimental, longitudinal, prospective, comparative, randomized trial in patients with diagnosis of bloody areas. Divided into control group and treatment group wich received supplementation with glutamine $(14 \mathrm{~g})$ and hydroxy methylbutyrate (3g) during 15 days. Tissue samples were taken for histopathologic evaluation. Differences between groups (Student's t) and effect size (Cohen's d) were analyzed. Results: Significant differences were reported in fibroblasts and angiogenesis ( $p$ $<0.005)$ with a large effect size $(\mathrm{d}>0.8)$; ly mphocytes and granulocytes without significant differences $(\mathrm{p}<0.005)$ but with medium effect size. No side effects were reported. Conclusions: The mixture of glutamine and Hydroxymethylbutyrate has a positive effect in the cells involved in the inflammatory and proliferative phase of healing.

Copy Right, IJAR, 2018,. All rights reserved.

\section{Introduction:-}

Nutrition in the patient with Diagnosis of bloody areas is a relevant is sue, to generate the homeostatic equilibrium of the patient. It should be noted that, during the healing process, the energetic-protein demands increase $\mathrm{e}^{1}$. This triggers a systemic inflammatory response that leads to an increase in metabolic demands; if there's also procedures such as trauma, burns, infections, and even the constant fasting to which these patients are subjected by the surgical toilet the protein requirement increases twice more than normal ${ }^{2,3,4,5,6}$. This contribution of energy and extra protein is necessary for the elaboration of cells involved in the wound healing process; if adequate substrates are not provided, this requirement is usually used from body reserves increasing the risk of muscle wasting, which leads to malnutrition ${ }^{4}$, delays angiogenesis, decreases collagen synthesis, prolongs the inflammatory phase involving damage to healthy tissue, decreases lymphocyte proliferation and the mechanical resistance of the skin delaying wound healing, resulting in chronic wounds ${ }^{7}$, leading up to a failed graft or flap. Within this context, the intake of the hospitalized patient does not meet the recommended daily requirement ${ }^{3-6,89}$ to achieve a positive effect on the 
immune system, specially on certain amino acids involved in wound healing. There is a $70 \%$ deficiency in the amino acids in hospitalized patients, so the nutritional support in these patients is essential since it restores the capacity of the immune response, specifically as glutamine and hydroxymethilbutirate (HMB) for the adequate immune function and cells proliferation.

Supplementation with glutamine $(14 \mathrm{~g} / \mathrm{d})$ and $\mathrm{HMB}(3 \mathrm{~g} / \mathrm{d})$ has positive effects, attributing benefits in the healing of wounds, through the increase of collagen deposits, ${ }^{12,13}$ muscle mass, ${ }^{18}$ lymphocytes and hemoglobin, ${ }^{20}$ decreasing wound size ${ }^{14-18}$ and inflammation. ${ }^{1921,22}$

The mix of these substances have demonstrated positive effects on patients who undergo this supplementation, a positive association has been observed in critical patients, post-surgical, diabetic foot, pressure ulcers, in patients with cancer and $\mathrm{HIV}^{23}$, attributing benefits in the wound healing, through increased collagen deposits and hydroxyproline blood levels ${ }^{24}$; however, the effect on the cells involved in the wound healing process is unknown. Given that, the phases of healing are characterized by the proliferat ion of cells of the immune system, it is very important to evaluate their evolution and prolife ration by histopathological analysis.

\section{Material and methods:-}

Clinical, experimental, longitudinal, prospective, comparative, randomized trial where patients older than 18 years, with diagnosis of bloody areas hospitalized in the Plastic and Reconstructive Surgery service during the period August 2016 - June 2018 with negative pressure system and those who signed the informed consent were included. Patients with previous supplementation, smokers, glycosylated hemoglobin> $12 \%$, renal failu re, topical collagen therapy, collagen vascular disease, autoimmune disease, radio or chemotherapy, allergy to any ingredient (glutamine or HMB), diagnosed with chronic diseases, pregnancy and lactation were excluded. Those patients who did not have adherence to the treatment, who underwent graft or flap skin procedure before completing the supplementation, voluntary discharges and patients who decided to withdraw their informed consent were eliminated.

Once the patient met the inclusion criteria, was invited to participate in the research protocol, explain ing what it consists of, as well as the benefits of Glutamine and HMB supplementation.

The protocol consisted in three stages:

First stage: Before the supplementation, under local anesthesia and by a standardized Medical Resident of the Plastic and Reconstructive Surgery Service, a sample of the edge of the affected tis sue was taken after asepsis or surgical toilet; this is a routine procedure in the Service, the sample was sent to the Pathology Service for analysis (procedure described later). Patients were randomly assigned to control or treatment group. Doctors and laboratory technicians, who worked with the participants in the study, as well as the participants themselves, were blinded to if the patients were assigned to treatment or control group. Second stage: If the patient was part of treatment group the supplement was delivered (box 1) explaining that it must be taken once a day during 15 days diluted in approximately $250 \mathrm{ml}$ of water. Individualized dietary guidance was given in order to improve nutritional status of participants. In case of being part of control group the patients was under observation during a period of 15 days .

Third stage: At the end of the supplementation, a second sample of the affected tissue was taken, by the procedure described above; to be analyzed in the laboratory by an experienced Physician Resident of the Pathology service.

Box 1.Nutritional composition of supplement per envelope and intake indications

\begin{tabular}{|l|l|}
\hline .Caloríes (kcal) & 68 \\
\hline Proteín (g) of which: & 17 \\
\hline A mino acids (g) of which: & 17 \\
\hline B-Hydro xy-methylbutirate (g) & 3 \\
\hline L-Glutamine (g) & 14 \\
\hline $\begin{array}{l}\text { Donated by: Evolution Nutraceutical Company S.A. de C.V. Prolongación Paseo de los Laureles No. 458-307. } \\
\text { Colonia Bosques de las Lomas, Ciudad de México. CP 05120 }\end{array}$ \\
\hline
\end{tabular}

The samples were analyzed by Giemsa stain for morphological differentiation in order to obtain the total number of units per field: ly mphocytes, macrophages, granulocytes, fibroblasts and angiogenesis. In addition, subjects were asked if they experienced any symptoms, such as stomachache, dizziness, nausea, vomiting, headache, loss of 
appetite, general weakness among others. A Kolmogorov-Smirnov test was used to check normality for continuous variables. A t-Student test was used for parametric data and Mann-Whitney U test for non parametric data.

The study was conducted under the established terms of the Mexican General Health Law, Title Five and the Regulations of the General Health Law on Health Research (RLGS), and NOM -012-SSA3-2012, which establish the criteria for the execution of research projects for human health. This study also counts with the approval of the Committee of Ethics in Research and the Research Committee of the General Hospital of Mexico "Dr. Eduardo Liceaga".

\section{Results: -}

A total of 21 patients were invited; 4 were excluded because the treatment was not properly concluded, leaving 17 patients, of whom 9 were assigned to the control group (53\%) and 8 to the treatment group (47\%). The mean age of the total sample was $38.65 \pm 14.47$ years (Table 1$)$.

\begin{tabular}{|c|c|c|c|c|c|}
\hline & Total & Mean age & $\mathrm{DS} \pm$ & Min & $\operatorname{Max}$ \\
\hline Total sample & $17(100 \%)$ & 38.35 & 13.97 & 18 & 59 \\
\hline Control & $9(53 \%)$ & 43.30 & 15.00 & 18 & 59 \\
\hline Treatment & $8(47 \%)$ & 30.00 & 10.00 & 19 & 49 \\
\hline
\end{tabular}

The control group had a mean age of $43.30 \pm 15.00$ years and treat ment group $30.00 \pm 10.00$ years.

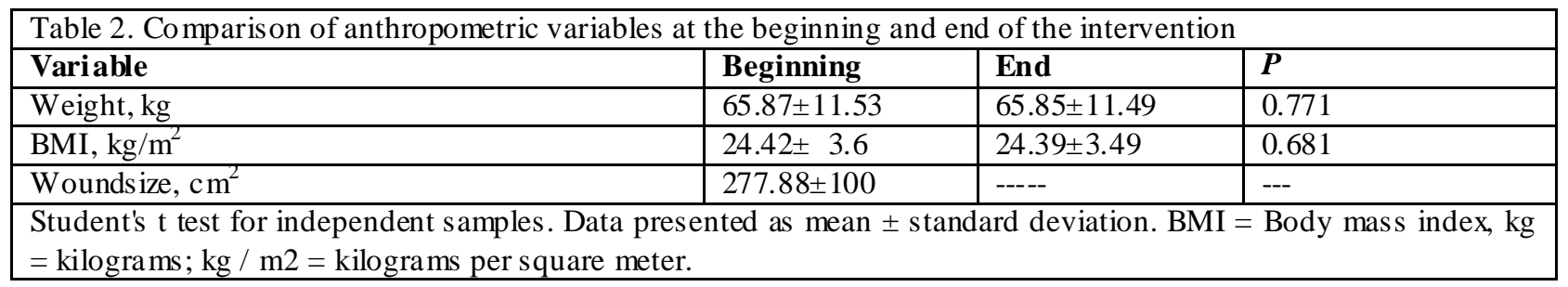

The mean weight before supplementation was $65.87 \pm 11.53 \mathrm{~kg}$ and at the end $65.85 \pm 11.49 \mathrm{~kg}$, no significant differences were found; BMI $24.42 \pm 3.6 \mathrm{~kg} / \mathrm{m}^{2}$ which is interpreted as a Normal body mass index according to the WHO and at the end $24.39 \pm 3.49 \mathrm{~kg} / \mathrm{m}^{2}$; no significant differences were found. The mean of the wounds size was $277.88 \pm 100 \mathrm{~cm}^{2}$, the final measurement was not obtained because some patients underwent a surgical procedure before taking the measure ment.

\begin{tabular}{|l|l|l|}
\hline Table 3. Ad mission Diagnosis & $\mathbf{N}$ & $\mathbf{\%}$ \\
\hline Diagnóstico de ingreso & 2 & 11.80 \\
\hline Bloody area by fire projectile & 7 & 41.20 \\
\hline Bloody area by car accident & 4 & 23.50 \\
\hline Bloody area by cold weapon & 4 & 23.50 \\
\hline Others & 4 \\
\hline Data is presented in frequencies and percentage respect to the total sample (n=17) & \\
\hline
\end{tabular}

The admission diagnosis with more frequency was car accident (41.20\%) followed by, cold weapon wound $(23.50 \%)$ and others $(23.50 \%)$ in which it is included: work accident, fall greater than two floors, everyday accident, with lower frequency by fire projectile $(11.80 \%)$

\begin{tabular}{|l|l|l|l|l|l|l|}
\hline \multicolumn{6}{|l|}{ Table 4. Units per field of the variab les before and after supplementation, compared by groups } & Treatment \\
\hline Variable & Control & Final & Inicio & Final & p & \\
\hline & Inicio & $8.44 \pm 3.35$ & $11.25 \pm 5.99$ & $12.50 \pm 7.69$ & 0.330 & 0.68 \\
\hline Lymphocytes & $11.56 \pm 5.45$ &
\end{tabular}




\begin{tabular}{|l|l|l|l|l|l|l|}
\hline Macrophages & $6.44 \pm 4.00$ & $5.44 \pm 4.64$ & $5.88 \pm 4.51$ & $5.00 \pm 2.44$ & 0.806 & 0.11 \\
\hline Granulocytes & $7.11 \pm 12.38$ & $6.44 \pm 6.78$ & $4.75 \pm 6.29$ & $11.25 \pm 10.25$ & 0.237 & 0.55 \\
\hline Fibroblasts & $4.89 \pm 2.80$ & $7.11 \pm 4.98$ & $6.25 \pm 3.10$ & $15.63 \pm 9.24$ & $* 0.015$ & 1.14 \\
\hline Angiogenesis & $3.89 \pm 3.01$ & $3.50 \pm 2.99$ & $3.89 \pm 2.89$ & $7.25 \pm 3.10$ & $* 0.036$ & 1.23 \\
\hline $\begin{array}{l}\text { Data presented in units per field }\left(\mathrm{mm}^{3}\right) \\
* \mathrm{p}<0.05\end{array}$ \\
\hline
\end{tabular}

At the end of the supplementation the control group had a lymphocytes mean of $8.440 \pm 3.35$ units/field and the treatment group: $12.50 \pm 7.69$ units/ field, without significant differences $(\mathrm{p}=0.330)$ but with a medium effect size $(\mathrm{d}=0.68)$; the macrophages in the control group of $5.44 \pm 4.64$ units/field and the treatment group $5.00 \pm 2.44$ units/field, without differences $(\mathrm{p}=0.806)$. A granulocyte mean of $6.44 \pm 6.78$ units/field was observed in the control group and $11.25 \pm 10.25$ units/field at treatment group, without significant differences $(p=0.237)$ with a medium effect size $(d=0.55)$ and an increased at the end in the treatment group. A tendency to increase in the fibroblast count was observed in both groups at the end of the treatment with significant differences between the means $(\mathrm{p}=0.015)$; with a large effect size $(\mathrm{d}=1.14)$. Finally, in the new blood vessel formation count $3.50 \pm 2.99$ units/field were reported in the control group and $7.25 \pm 3.10$ units/field in the treatment group, with significant differences $(p=0.036)$, and a large effect size. $(\mathrm{d}=1.23)($ Graph 1$)$.

Graph 1:- Histogram of units/field \pm standard deviation between groups after treatment

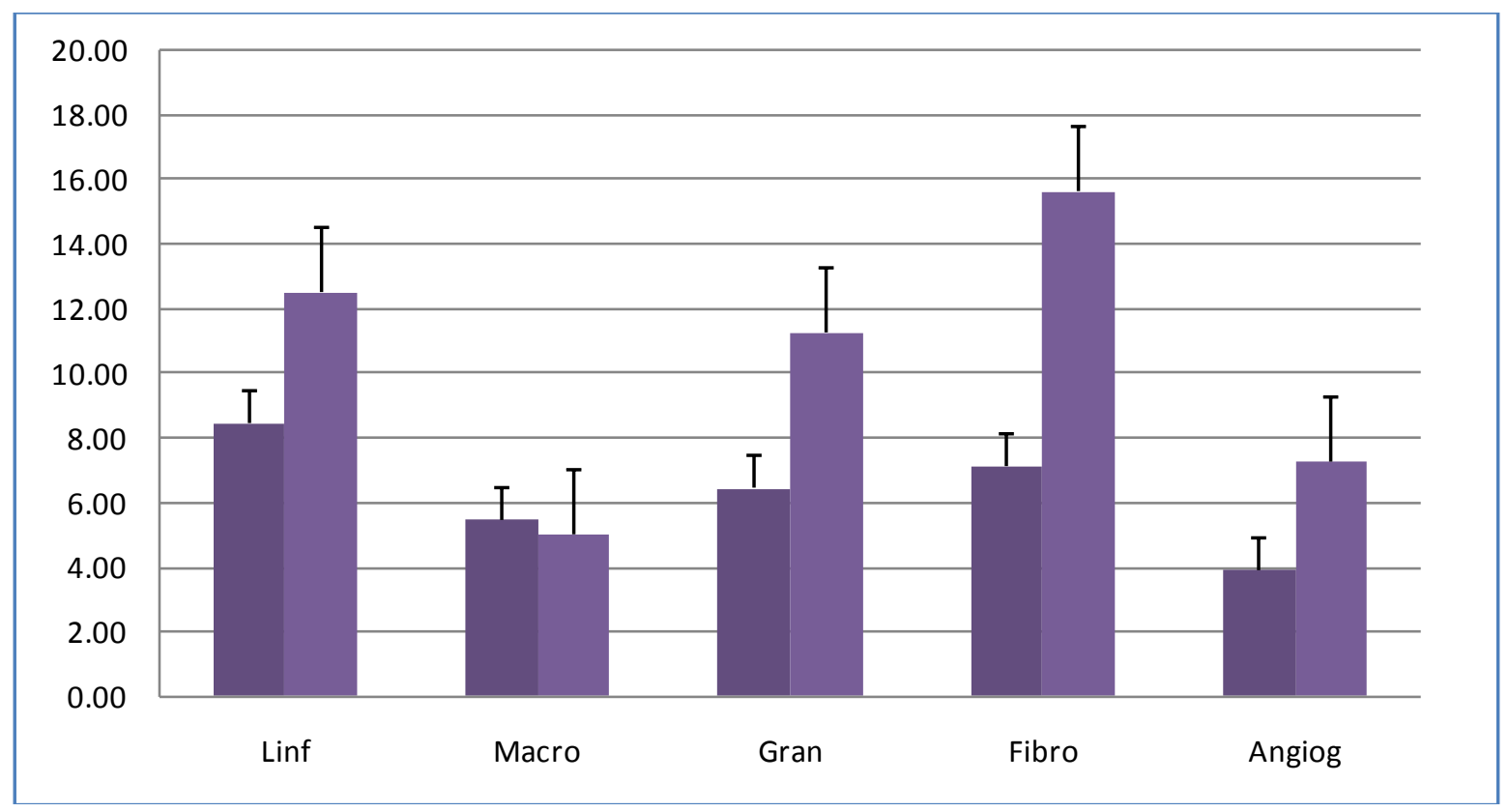

On a daily basis, a symptomatology questionnaire was applied to the patients in both groups, the frequencies at the end of the supplementation are shown in the following table:

\begin{tabular}{|l|l|l|l|l|}
\hline \multicolumn{5}{|l|}{ Table 5. Nu mber of patients who continued with symptomatology at term by experimental group } \\
\hline & control & treatment & \\
\hline Symptomatology & Before $\mathrm{n}_{1}(\%)$ & After $\mathrm{n}_{1}(\%)$ & Before $\mathrm{n}_{2}(\%)$ & After $_{2}(\%)$ \\
\hline Stomachache & $2(22.2)$ & $1(11.1)$ & $1(12.5)$ & $0(0.00)$ \\
\hline Vomitting & $2(22.2)$ & $1(11.1)$ & $1(12.5)$ & $0(0.00)$ \\
\hline Nauseas & $5(55.5)$ & $2(22.2)$ & $3(37.5)$ & $0(0.00)$ \\
\hline General weakness & $6(66.6)$ & $2(22.2)$ & $6(75.0)$ & $1(12.50)$ \\
\hline Headache & $2(2.22)$ & $0(0.0)$ & $2(25.0)$ & $0(0.00)$ \\
\hline Badmood & $2(22.2)$ & $3(33.3)$ & $3(37.5)$ & $1(12.50)$ \\
\hline
\end{tabular}




\begin{tabular}{|l|l|l|l|l|l|}
\hline Edema & $5(55.5)$ & $2(22.2)$ & $3(37.5)$ & $2(25.0)$ \\
\hline Diarrhea & $4(44.4)$ & $2(22.2)$ & $3(37.5)$ & $0(0.00)$ & \\
\hline Constipation & $1(11.1)$ & $0(0.0)$ & $3(37.5)$ & $1(12.50)$ & \\
\hline Appetite loss & $4(44.4)$ & $2(22.2)$ & $4(50.0)$ & $0(0.00)$ & \\
\hline $\begin{array}{l}\text { Data presented in frequencies and percentages before and after supplementation referring to the number of patients } \\
\text { who presented the symptomatology. } \mathrm{n} 1=9 \text { patients in the control group, n2 = 8 patients in the treatment group. }\end{array}$ \\
\hline
\end{tabular}

At the end of 15 days the control group showed higher frequencies in symptomatology compared to the treatment group. In first place, there is a decrease in the frequency of patients who showed general weakness in the treatment group from $75 \%$ to $12.50 \%$, who reported an increase in the sensation of physical energy. There was a decrease in loss of appetite frequency from 4 to 0 ; to which the patients of this group reported an increase in the appetite sensation. A decrease in gastrointestinal symptoms such as diarrhea from $37.5 \%$ to $0 \%$ was also reported, indicating better consistency in the evacuations. The feeling of nausea decreased in both groups, from $55.5 \%$ to $22.2 \%$ in the control group and from $37.5 \%$ to $0.0 \%$ in the treatment group. These symptoms were reported before the supplementation and patients themselves related nausea and vomitting to anesthesia side effects.

\section{Discussion:-}

It is considered, that this is one of the few formal researches studies that have been accomplished with: glutamine $(14 \mathrm{~g} / \mathrm{d})$ and hydroxymethylbutyrate (HMB 3g/d), since the literature review yielded little information about it and arginina has been added to the mixture in other studies. The biggest effect was observed in Fibroblasts and Angiogenesis, both reported significant differences between groups at the end of the supplementation, with a large effect size. In comparison with another study of similar characteristics where the histology of the wound was evaluated subjectively (inflammation, reepithelialization, granular tissue, collagen and angiogenesis) where no significant differences were found between the parameters attributed to the lack of standardization in the protein supplementation between groups $(p>0.05)^{25}$.

The tendency to increase found in the results agree with that described by Witte et al. about the difference in appearance time of the cells in the wound during the healing process, macrophages are predominant during inflammation taking its maximum peak between the 4th and 6th day after the wound, while the lymphocyte count increases to its maximum peak on the 6th day and a decrease is expected from day 10-14, this cells are predominant, along with the fibroblasts, during the proliferative phase with maximum peaks around day 8-13 rising to the maturation phase, decreasing the degradation of the damaged extracellular matrix and increasing the production of collagen $\mathrm{III}^{26}$.

Biochemical parameters were measured in order to monitor the protein metabolism such as albumin, total proteins, blood urea nitrogen and creatinine, no significant differences were observed and levels were mantained within normal range which is why the results are not reported. Results differ from reported by Rathmacher where blood urea nitrogen increased in a HMB+arg inina+glutamine supplemented group unlike the results in this study, mainly because the supplementation was different resulting as extra nitrogen consumed, so it is relevant to evaluate the importance or not of arginine in supplementation. ${ }^{26}$

Regarding the symptomatology, in general a decrease of the symptomatology was reported in both groups, it is worth mentioning that, the patients who received the treatment reported improvement in: general well-being, increased appetite and better intestinal transit (referred to as a better consistency in the evacuations by those who presented diarrhea and a higher number of evacuations in those who presented constipation); which was not referred by the control group. Benefits of intestinal permeability have been reported when supplemented with glutamine ${ }^{27}$, mainly by decreasing the duration of diarrhea since it helps to maintain the intestinal immunological barrier, increasing the levels of intestinal immunoglobulin A, reduces bacterial translocation and promotes the absorption of sodium and water by functioning as a substrate in the co-transport of sodium; Therefore, it reduces the duration and frequency of gastrointestinal symptoms ${ }^{28,29}$.

It should be mentioned that the sample size could have limited the results of the study, despite this; the results demostrate that the mixture of glutamine and HMB as daily supplementation can have a positive effect on the cells involved in the healing process. It is considered that the perspective of the study is to continue the research on the benefits of immunonutrition on wound healing in different pathologies, in addition the need to carry out a new study 
including cluster differentiation in order to specifically identify the type of cells observed and designing and in which the long-term permanence of the effect can be evaluated.

\section{Acknowledge ments:-}

We kindly thank Evolution Nutraceutical Company S.A. of C.V. for the donation of amino acids without conflict of interest.

\section{References:-}

1. Quain A, Khardori M. Nutrition in Wound Care Management: A comprehensive Overview. Wounds. 2015; 27(12):327-35.

2. Dryden S, Shoemaker W, Kim J. Wound Management and Nutrition for Optimal Wound Healing. Atlas Oral Maxillofacial SurgClin N Am. 2013; 21(1):37-47.

3. Montoya-Montoya N, Munera-García. Efecto de la intervención nutricional temprana en el resultado clínico de pacientes con riesgo nutricional. Nutr Hosp. 2014; 29(1) 427-36.

4. Stechmiller J. Understanding the Role of Nutrition and Wound Healing. Nutrition in Clin icalPractice. Nutr Clin Pract. 2010; 25(1):61-8.

5. Vesga A, Ganboa E. Riesgo de malnutrición asociado a baja ingesta alimentaria, estancia hospitalaria prolongada y reingreso en un hospital de alto nivel de complejidad en Colo mbia. Nutr Hosp. 2015; 32(3):13081314.

6. Rodríguez B, Laquaniti N, Merkel M, Villagra A. PolíticaNutricionalactiva en la implementación del soporte nutricional hospitalario; resultados de un estudio observacional. Nutr Hosp. 2014; 30(2):447-452.

7. Harris C, Bates-Jensen B, Parslow N, Raizman R, Singh M. The Bates-Jensen Wound Assessment Tool (BWAT): Develop ment of a Pictorial Gu ide for Training Nurses. Wound Care Canada. 2009 Ju lio; 7(2): $253-9$.

8. 8.Baker L, Gout B, Crowe T. Hospital Malnutrition; prevalence, identification and impact on patients and the healthcare system. Int J Environ Res Public Health 2011; (8): 514-527.

9. Lizaka S, Okuwa M, Sugama J, Sanada H. The impact of malnutrition and nutrition-related factors on the development and severity of pressure ulcers in older patients receiving ho me care. Clin Nutr 2010; (29):47-53

10. Chow O, Barbul A. Inmunonutrition: Role in Wound Healing and Tissue Regeneration. WHS. 2012; 3(1): 4653.

11. Uscategui H. In munonutrición: Enfoque en el paciente quirúrg ico. Rev ChilCirc 2010; 62 (1): 87-92.

12. Durkalec K, Jeszka J, Podgorski T. The effect of a 12-week beta-hydroxy-beta-methylbutirate (HMB) Supplementation on Highly-Trained Combat Sports Athletes: A randomized, double-blind, placebo-controlled crossover study. Nutrients, 2017; (9): 1-21.

13. Jones M, Rivera M, Puccinelli C, Wang M, Williams S, A B. Targeted A mino Acid Supplementation in Diabetic Foot Wounds: Pilot Data and a Review of the Literature. Surgical Infections. 2014; 15(6): 708-12.

14. Cruz-Jentoff A. Beta-hydroxy-beta-methyl butyrate (HMB): From experimental data to clinical evidence in sarcopenia. Curr Protein Pept Sci. 2017; (28): 668-672.

15. Wing A, Chow A, Wang A, Ong L, Zhang S, Young S. The use of a specialized amino acid mixture for pressure ulcers: A placebo-controlled trial. Journal of Wound Care. 2014; 23(5): 259-60, 262-4, 266-9.

16. Armstrong D, Hanft J, Driver V, Smith P, Lazaro J, Reyzelman A, et al. Effect of oral nutritional supplementation on wound healing in diabetic foot ulcers: a prospective randomized controlled trail. Diabet Med. 2014; 31.

17. Sipahi S, Gungor O, Gunduz M, Cilci M, Cahit M, Tamaer A. Te effect of oral supplementation with a combination of beta-hydroxy-beta-methylbutirate, arginine, and glutamine on wound healing: a retrospective analys is of diabetic haemodialys is patients. BMC Nephrol 2013; 14(8): 1-6. .

18. Wandrag L, Brett S, Frost G, Hicks on M. Impact of supplementation with amino acids or their metabolites on muscle wasting in patients with critical illness or other muscle wasting illness: a systematic review. J Hum Nutr Diet. 2015; $28(4): 313-30$.

19. Haldun R, Temel H, Os man B, Ersoy E, Yazgan A, Yild irim Z. The mixtu re of Arginine, Glutamine, and Bhydroxy-b-methyl Butyrate Enhances the Healing of Ischemic Wounds in Rats. JPEN J Parenter Enteral Nutr. 2017; 41(6):1045-1050.

20. Yavas C, Yavas G, Acar H, Toy H, Yuce D, Akyurek S, et al. A melioration of radiation-induced acute inflammation and mucosal atrophy by beta-hydroxy-beta-methylbutyrate, L-glutamine, and L-argin ine: results of an experimental study. Support Care Cancer 2013; (21):883-888 
21. Wu H, Xia Y, Jiang J, Du, Guo X, Liu X, et al. Effect of beta-hydroxy-beta-methylbutirate supplementation on muscle loss in older adults: A systematic review and meta-analysis. Arch Gerontol Geriatr. 2015; 61 (2):168-75.

22. Sipahi S, Gungor O, Gunduz M, Cilci M, Cahit M, Tamer A. The effect of oral supplementation with a combination of beta-hydroxy-beta-methylbutyrate, arginine and glutamine on wound healing: a retrospective analys is of diabetic haemodialys is patients. BMC Nephrol. 2013; (14)8: 1-6.

23. May P, Barber A, D’Olimpio J, Hourihane A, Abumrad N. Reversal of cancer-related wasting using oral supplementation with a comb ination of beta-hydroxy-beta-methylbutyrate, arginine, and glutamine. A m J Surg. 2002; (182): 471-479.

24. Clark R, Feleke G, Din M, Yas min T, Singh G, Khan F, et al. Nutritional Treatment for Acquired Immunodeficiency Virus - Associated Wasting Using $\beta$-Hydroxy $\beta$-Methylbutyrate, Glutamine, and Arginine: A Randomized, Double-Blind, Placebo-Controlled Study. Eur J Clin Nutr. 2016; 70(2): 269-273.

25. Osman B, Riza H, Eren E, cols y. A Pilot experimental study on the effect of arginine, glutamine, and bhydroxy-b-methylbutyrate on secondary wound healing JPEN J Parenter Enteral Nutr. 2017 Aug;41(6):10451050.

26. Ratchmater J, Nissen S, Panton L, Clark R, May P, Barber A, et al. Supplementation with a combination of beta-hydroxy-beta-methylbutyrate (HMB), arginine, and glutamine is safe and could improve hematological parameters. JPEN J Parenter Enteral Nutr. 2004; 28(2):65-75.

27. Witte M, Barbul A. General principles of wound healing. Surg Clin North Am. 1997; 77(3):509-28.

28. Achamrah N, De'chelotte P, Coe"ffier M. Glutamine and the regulation of intestinal permeability: from bench to bedside. Curr Opin Clin Nutr Metab Care. 2017; 20(1):86-91.

29. Bardhan P. Improving the ORS: Does Glutamine have a Role? J Health Popul Nutr. 2007; 25(3): $263-266$. 